\title{
Purification and characterization of a proteinaceous compound from Pseudomonas fluorescens ATCC 948 with inhibitory activity against some Gram-positive and Gram-negative bacteria of dairy interest
}

\author{
M Gobbetti *, A Corsetti, E Smacchi, J Rossi \\ Institute of Dairy Microbiology, Agriculture Faculty, S Costanzo 06126, Perugia, Italy
}

(Received 21 May 1996; accepted 16 September 1996)

\begin{abstract}
Summary - A proteinaceous antimicrobial compound from Pseudomonas fluorescens ATCC 948 was purified to homogeneity by chromatography steps and characterized. The compound showed a large spectrum of activity. Inhibition of thermophilic Lactobacillus, Listeria monocytogenes, Enterobacteriaceae and $P$ fluorescens strains was mainly detected. The antimicrobial compound produced in skim milk had an apparent molecular mass of $67 \mathrm{kDa}$, was quite heat-stable $\left(80^{\circ} \mathrm{C}\right.$ for $15 \mathrm{~min}$ ), insensitive to lipase and $\alpha$-amylase, and completely inactivated by treatment with proteolytic enzymes. A bactericidal mode of action was detected against Lactobacillus fermentum D13 chosen as indicator strain. P fluorescens ATCC 948 was not sensitive to the antimicrobial compound produced by itself. The production of the proteinaceous substance started in the early exponential phase of growth, and was highest after $72 \mathrm{~h}$ of incubation at $20^{\circ} \mathrm{C}$ and $\mathrm{pH} 6.5$. Some considerations about the nature of the antimicrobial compound are given.
\end{abstract}

Pseudomonas fluorescens / proteinaceous antimicrobial compound / thermophilic Lactobacillus

Résumé - Purification et caractérisation d'une substance protéinique par Pseudomonas fluorescens ATCC 948, avec activité d'inhibition contre certaines bactéries Gram positives et Gram négatives d'intérêt laitier. Une protéine présentant une activité antimicrobienne a été produite par Pseudomonas fluorescens ATCC 948. Elle a été purifiée jusqu'à homogénéité par chromatographie et caractérisée. Elle présente un large spectre d'activité et une inhibition contre certaines souches de Lactobacillus thermophiles, contre Listeria monocytogenes, Enterobacteriaceae et des souches de P fluorescens. Le composé antimicrobien produit dans du lait écrémé présente un poids moléculaire apparent de $67 \mathrm{kDa}$, est suffisamment thermostable $\left(80^{\circ} \mathrm{C}\right.$ pendant 15 minutes), pas sensible à la lipase et à l' $\alpha$-amylase, mais est complètement inactivé par traitement aux enzymes protéolytiques. Son mode d'action bactéricide a été determiné contre Lactobacillus fermentum D13, choisi comme souchetémoin. P fluorescens ATCC 948 n'est pas sensible au composé antimicrobien produit par lui-même.

* Correspondence and reprints 
La production de cette substance protéinique a commencé pendant la première phase de développement exponentiel, et a été la plus importante après 72 heures d'incubation à $20^{\circ} \mathrm{C}$ et $\mathrm{pH} 6,5$. Quelques considérations concernant la nature du composé protéinique ont été proposées.

Pseudomonas fluorescens / composé antimicrobien protéinique / Lactobacillus thermophile

\section{INTRODUCTION}

Psychrotrophic pseudomonads are the most common microorganisms that grow in raw milk during cold storage (Cousin, 1982). Pseudomonas fluorescens has been shown to secrete extracellular lipases, and especially proteinases, which are resistant to both pasteurization and UHT treatments (Griffiths et al, 1981). Proteinases cause bitterness in UHT milk (Gobbetti, 1993) and contribute, together with plasmin, to age gelation of unconcentrated UHT milk (de Koning et al, 1985).

Several studies have been conducted on the inhibitory effect of lactic acid bacteria against Pseudomonas strains. Inhibition of psychrotrophic pseudomonads, either by lowering $\mathrm{pH}$, producing lactic acid and hydrogen peroxide or by more complex microbial interactions, has been shown with Leuconostoc mesenteroides subsp dextranicum (Mans De Marion et al, 1995); commercial lactic cultures (Champagne et al, 1990 ) inoculated in raw milk stored at low temperature; lactic acid bacteria starters used in cultured milks (Balasubramanyam and Varadaraj, 1994); culture supernatants of strains of Bifidobacterium cultivated in skim milk (Mitsuhashi and Murata, 1991) and with neutralized extracellular culture filtrates of Lactobacillus and Lactococcus species (Varadaraj et al, 1993). On the contrary, psychrotrophic pseudomonads which are initially not antagonized can promote the lactic acid bacteria metabolism by their proteolytic products (Koburger and Claydon, 1961; Tayfour et al, 1981) and by urease activity, which produces a decrease in the amount of native urea of milk and increases in the ammonia concentration (Jaspe et al, 1995).

To our knowledge, no reports have been made on the antagonistic activity of psychrotrophic pseudomonads towards lactic acid bacteria. Siderophores, pterines, indoles, phenazynes, lipids, peptides and bacteriocins are produced by Pseudomonas spp strains and have been extensively studied for their antimicrobial activity in the biocontrol of plant diseases (Dowling and $\mathrm{O}^{\text {' }}$ Gara, 1994). Bacteriocins from $P$ glycinea, $P$ phaseolicola (Vidaver et al, 1972), $P$ syringae pv syringae (Smidt and Vidaver, 1986), $P$ syringae subsp savastanoi (Iacobellis et al, 1995), $P$ solanacearum (Cuppels et al, 1978) and $P$ fluorescens (Reeves, 1965) have been isolated and characterized. A narrow spectrum of activity, in particular shown against important plant pathogens, is a common feature of pseudomonad bacteriocins: several studies (Cuppels et al, 1978; Iacobellis et al, 1995) have shown a species-specific inhibition. There are some strains, however, that have shown a wider spectrum of antagonism, including unrelated Gram-negative and Gram-positive species.

Analogous interactions have been reported in foods. Inhibition of foodborne bacteria by Pseudomonas spp has been observed and attributed to siderophores or bacteriocin-like substances (Freedman et al, 1989; Champomier-Vergès and Richard, 1994) but inhibition of unrelated Bacillus cereus and Listeria spp strains has only been detected in a few strains (Freedman et al, 1989). 
In this study, a proteinaceous compound with inhibitory activity mainly towards lactic acid bacteria has been purified and characterized from $P$ fluorescens ATCC 948.

\section{MATERIALS AND METHODS}

\section{Strains and culture conditions}

Pseudomonas fluorescens ATCC 948 and the other pseudomonad strains isolated from raw milk (Gobbetti and Rossi, 1992), were aerobically cultivated in nutrient broth (BN) (Difco Laboratories, Detroit, MI, USA) at $28{ }^{\circ} \mathrm{C}$ for $24 \mathrm{~h}$. Mesophilic and thermophilic Lactobacillus and Enterococcus strains were propagated in MRS (De Man et al, 1960), streptococci and lactococci in M17 (Difco) with $0.5 \%$ glucose (GM17); Enterobacteriaceae in McConkey medium (Difco) with $0.5 \%$ glucose; Listeria monocytogenes in TSY (Difco) and Bacillus strains in BN (Difco) media.

\section{Production of culture supernatants and detection of antagonistic activity}

Pseudomonas fluorescens ATCC 948 and 20 other strains were grown at $28^{\circ} \mathrm{C}$ for $48 \mathrm{~h}$ in $\mathrm{BN}$ or skim milk, the cells were harvested by centrifugation (7000 $\mathrm{g}$ for $10 \mathrm{~min}$ ), and the supernatants adjusted to $\mathrm{pH} 6.5$ and filtered through a $0.22 \mu \mathrm{m}$ pore size filter (Nucleopore; Costar Corp, Cambridge, MA, USA). Due to the proteolytic activity of $P$ fluorescens ATCC 948 during the 48-h growth period, a limpid whey was also harvested by the centrifugation of cells grown in skim milk. To detect antagonistic activity, a well-diffusion assay was used (Schillinger and Lücke, 1989). The assays were conducted in different agar media (specific for each indicator strain) overlaid with $7 \mathrm{~mL}$ of different soft agar media which contained $4 \%$ inoculum of an overnight culture of the indicator strain. Wells, $3 \mathrm{~mm}$ in diameter, were cut into these agar plates and filled with $300 \mu \mathrm{L}$ of the culture supernatant of the potential producer strain. The plates were incubated for $24 \mathrm{~h}$ at 28 or $37^{\circ} \mathrm{C}$ and subsequently examined for zones of inhibition. Inhibition was scored positive if the width of the clear zone around the wells was $1.0 \mathrm{~mm}$ or larger.
A quantitative determination based on a critical dilution assay (Barefoot and Klaenhammer, 1983) was used to express the arbitrary units (AU) of antimicrobial activity. An AU was defined as the maximum dilution of the antimicrobial compound preparation which inhibited Lb fermentum D13 after 24 h of incubation at $37{ }^{\circ} \mathrm{C}$.

\section{Purification of the antimicrobial compound}

Five $\mathrm{L}$ of the supernatant culture of $P$ fluorescens ATCC 948 in BN medium were concentrated 30-fold by freeze-drying (Edwards MOD E1PTB; Edwards, Milan, Italy), resuspended in $50 \mathrm{mmol} / \mathrm{L}$ phosphate buffer, $\mathrm{pH} 7.0$ and crystalline ammonium sulphate was gradually added with slow stirring until $50 \%$ saturation was reached. The mixture was kept overnight at $4{ }^{\circ} \mathrm{C}$ for complete precipitation and then centrifuged at $15000 \mathrm{~g}$ for $15 \mathrm{~min}$. The precipitate was dissolved in $20 \mathrm{mmol} / \mathrm{L} \mathrm{Na}$-acetate buffer, $\mathrm{pH} 5.0$, dialyzed for $24 \mathrm{~h}$ at $4{ }^{\circ} \mathrm{C}$ and applied to a S-Sepharose HR 16/50 column (Pharmacia Fine Chemicals, Uppsala, Sweden), equilibrated with the same buffer. After washing, elution was carried out at a flow rate of $35 \mathrm{~mL} / \mathrm{h}$ with a linear $\mathrm{NaCl}$ gradient, 0.1 to $0.5 \mathrm{~mol} / \mathrm{L}$. As for the other purification steps, the collected fractions $(7 \mathrm{~mL})$ were tested for inhibition against $L b$ fermentum D13 by the well-diffusion method. This bacterium was chosen as indicator because, among the lactic acid bacteria, it had shown an intermediate sensitivity to the antimicrobial compound. Fractions with strong inhibitory activity were pooled, dialyzed for $24 \mathrm{~h}$ at $4{ }^{\circ} \mathrm{C}$ against $5 \mathrm{mmol} / \mathrm{L}$ phosphate buffer, $\mathrm{pH} 7.0$ and concentrated 10 -fold by freeze-drying.

Inhibitory fractions from the previous step were redissolved in a small volume of $50 \mathrm{mmol} / \mathrm{L}$ phosphate buffer, $\mathrm{pH} 7.0$, and further purified by gel-filtration on Superose $12 \mathrm{HR} 10 / 30 \mathrm{col}-$ umn (Pharmacia), equilibrated with $50 \mathrm{mmol} / \mathrm{L}$ phosphate buffer, $\mathrm{pH} 7.0$, containing $0.15 \mathrm{~mol} / \mathrm{L}$ of $\mathrm{NaCl}$. Elution with the same buffer was at a flow rate of $40 \mathrm{~mL} / \mathrm{h}$ and $1-\mathrm{mL}$ fractions were collected and assayed for inhibition.

The pooled, dialyzed and 10-fold concentrated inhibitory fractions from gel-filtration were finally purified on a FPLC-Mono-Q HR 5/5 column (Pharmacia). Elution was made with $20 \mathrm{mmol} / \mathrm{L}$ Bis-Tris propane buffer, $\mathrm{pH} 6.5$, by a linear $\mathrm{NaCl}$ 
gradient $(0$ to $0.3 \mathrm{~mol} / \mathrm{L})$ at a flow rate of $45 \mathrm{~mL} / \mathrm{h} ; 0.5-\mathrm{mL}$ fractions were collected.

\section{Protein determination}

The protein concentration in the solutions containing the antimicrobial compound was determined by the method of Bradford (1976), using bovine serum albumin as standard. The protein concentration during the purification steps was monitored by measuring absorbance at $280 \mathrm{~nm}$.

\section{Electrophoresis}

Purity and molecular mass of the proteinaceous compound were estimated by SDS-PAGE. $\beta$-Galactosidase (116.4 kDa), fructose-6-phosphate kinase $(85.2 \mathrm{kDa})$, glutamate dehydrogenase $(55.6 \mathrm{kDa})$, aldolase $(39.2 \mathrm{kDa})$ and triosephosphate isomerase $(26.6 \mathrm{kDa}$ ) were used as molecular mass markers (Boehringer Mannheim GmbH, Germany). The SDS-PAGE was conducted according to Laemmli's procedure (1970); gels contained 10\% acrylamide (separation distance, $10 \mathrm{~cm}$; gel thickness, $1 \mathrm{~mm}$ ). The protein samples were mixed 1:1 with sample buffer $(0.18 \mathrm{~mol} / \mathrm{L}$ Tris- $\mathrm{HCl}, \mathrm{pH} 6.8,0.3 \%$ SDS, $8.6 \%$ glycerol, $1 \%$ mercaptoethanol and $0.07 \%$ bromophenol blue) and applied to the gels. Electrophoresis was performed at $200 \mathrm{~V}$ for approximately $45 \mathrm{~min}$. Gels were stained with Coomassie brilliant blue R250 (Sigma Chemical Co, St Louis, MO, USA).

\section{Characterization of the antimicrobial compound}

\section{Sensitivity to heat and hydrolytic enzymes}

Solutions of the purified antimicrobial compound in $50 \mathrm{mmol} / \mathrm{L}$ phosphate buffer, $\mathrm{pH} 7.0$, were heated at 80 to $100^{\circ} \mathrm{C}$ for 5 to $20 \mathrm{~min}$, and the remaining activity was determined by well-diffusion assay.

The following enzymes (Sigma Chemical Co, St Louis, MO, USA) were tested for their hydrolytic activity on the purified antimicrobial compound: proteinase $\mathrm{K}(2.6 \mathrm{U} / \mathrm{mg})$, trypsin (22 U/mg), proteinase B500 (45 U/mg), lipase $(50 \mathrm{U} / \mathrm{mg}$ ) and $\alpha$-amylase $(15 \mathrm{U} / \mathrm{mg}$ ). The assays were performed at a final concentration of $0.5 \mathrm{mg} / \mathrm{mL}$ and at $\mathrm{pH} 6.5$, except for pepsin (pH 3.0). Samples with and without enzymes were held at $35^{\circ} \mathrm{C}$ for $6 \mathrm{~h}$ and the remaining activity was determined by well-diffusion assay.

\section{Mode of action}

To study the effect of the antimicrobial compound from $P$ fluorescens ATCC 948 on sensitive cells, $2 \mathrm{~mL}$ of a 30 -fold concentrated (under vacuum), adjusted to $\mathrm{pH} 6.5$ and filtered supernatant (specific activity, $37.5 \mathrm{AU} / \mathrm{mg}$ ) were added to $10 \mathrm{~mL}$ of MRS broth containing $L b$ fermentum D13 in a cell concentration of $\log 5.2 \mathrm{cfu} / \mathrm{mL}$. For comparison, a concentrated supernatant from $P$ fluorescens $\mathrm{M} 8$, which is not a producer of antimicrobial compound, was used. At 3-h intervals, the number of viable cells was determined on MRS agar plates after incubation at $37^{\circ} \mathrm{C}$ for $48 \mathrm{~h}$.

To determine whether the compound was bacteriostatic or bactericidal, the $L b$ fermentum D13 cells were cultivated for $9 \mathrm{~h}$ in MRS broth containing the lowest inhibitory concentration of the compound ( $5 \mathrm{AU} / \mathrm{mg}$ ), the broth was then diluted 5 -fold by the addition of MRS and the growth of cells was allowed to continue for $48 \mathrm{~h}$ at $37{ }^{\circ} \mathrm{C}$ before plating.

\section{Phase of growth, pH and temperature optima}

$P$ fluorescens ATCC 948 cells were cultivated on BN medium and skim milk at $28^{\circ} \mathrm{C}$ for $144 \mathrm{~h}$ and samples were taken at different periods of time to determine the inhibitory activity on Lb fermentum D13.

The influence of the $\mathrm{pH}$ and temperature on the production of the proteinaceus antimicrobial compound was assayed by growing $P$ fluorescens ATCC 948 in BN medium, $\mathrm{pH} 4.0-8.0$, and in BN medium, $\mathrm{pH} 7.0$, and at temperatures of 5 to $40^{\circ} \mathrm{C}$.

\section{RESULTS}

\section{Inhibitory spectrum of the antimicrobial compound}

The inhibitory spectrum of the antimicrobial compound contained in the extracellular supernatant of $P$ fluorescens ATCC 948 culture in BN broth is shown in table I. No 
Table I. Inhibitory spectrum of the antimicrobial compound produced by $P$ fluorescens ATCC 948.

Spectre d'inhibition du composé antimicrobien produit par $\mathrm{P}$ fluorescens ATCC 948.

\begin{tabular}{|c|c|c|c|}
\hline Indicator species & Strain no & Origin $^{\mathrm{a}}$ & Inhibition ${ }^{\mathrm{b}}$ \\
\hline \multicolumn{4}{|l|}{ Gram-positive bacteria } \\
\hline Bacillus subtilis & S21 & Our strain collection & - \\
\hline$B$ cereus & 7464 & NCTC & - \\
\hline Enterococcus faecalis & E58 & Our strain collection & - \\
\hline Efaecalis & E71 & Our strain collection & - \\
\hline Efaecium & E34 & Our strain collection & - \\
\hline Lactobacillus plantarum & 2741 & UCC & $(+)$ \\
\hline Lb plantarum & 2739 & UCC & - \\
\hline Lb pseudoplantarum & 2742 & UCC & $(+)$ \\
\hline Lb pseudoplantarum & 2745 & $\mathrm{UCC}$ & - \\
\hline Lbcasei & 2752 & $\mathrm{UCC}$ & - \\
\hline Lb casei & 2756 & $\mathrm{UCC}$ & - \\
\hline Lb curvatus & 2081 & UCC & - \\
\hline Lb curvatus & 2042 & UCC & - \\
\hline Lb bulgaricus & B397 & Our strain collection & ++ \\
\hline Streptococcus thermophilus & F142 & Our strain collection & + \\
\hline Lb acidophilus & A2 & Our strain collection & $(+)$ \\
\hline Lb acidophilus & N2 & Our strain collection & $(+)$ \\
\hline Lb fermentum & DT41 & Our strain collection & $(+)$ \\
\hline Lb fermentum & D13 & Our strain collection & + \\
\hline Lb helveticus & PR4 & Our strain collection & ++ \\
\hline Lb lactis & DT42 & Our strain collection & + \\
\hline Lb reuteri & 20016 & Our strain collection & $(+)$ \\
\hline Lactococcus lactis ssp lactis & MG1363 & Our strain collection & - \\
\hline Listeria monocytogenes & $\mathrm{X} 88$ & Our strain collection & + \\
\hline Staphylococcus aureus & M35 & Our strain collection & $(+)$ \\
\hline \multicolumn{4}{|l|}{ Gram-negative bacteria } \\
\hline Pseudomonas fluorescens & 948 & ATCC & - \\
\hline$P$ fluorescens & M4 & Our strain collection & + \\
\hline Pfluorescens & M8 & Our strain collection & - \\
\hline$P$ fluorescens & M20 & Our strain collection & - \\
\hline$P$ fluorescens & M22 & Our strain collection & + \\
\hline$P$ fluorescens & M30 & Our strain collection & - \\
\hline$P$ fluorescens & M31 & Our strain collection & - \\
\hline P fluorescens & M40 & Our strain collection & - \\
\hline Pfluorescens & M44 & Our strain collection & $(+)$ \\
\hline$P$ fluorescens & M45 & Our strain collection & - \\
\hline P fluorescens & M47 & Our strain collection & $(+)$ \\
\hline Proteus vulgaris & $\mathrm{X} 31$ & Our strain collection & $(+)$ \\
\hline Salmonella ssp & X14 & Our strain collection & $(+)$ \\
\hline Serratia liquefaciens & X53 & Our strain collection & + \\
\hline Shigella & $\mathrm{X} 23$ & Our strain collection & - \\
\hline
\end{tabular}

${ }^{a}$ Abbreviations: NCTC: National Collection of Type Cultures (London); ATCC: American Type Culture Collection (Rockville, MD); UCC: Culture Collection of the Department of Food Chemistry of University College Cork, Ireland; ${ }^{b}$ Symbols: ++: very large inhibition zone (> $\left.5.0 \mathrm{~mm}\right) ;+$ : large inhibition zone $(>2.0$ $\mathrm{mm}) ;(+)$ : small inhibition zone $(2.0-1.0 \mathrm{~mm}) ;-$ : no inhibition zone. 
differences were detected by cultivating the strain in skim milk. The large spectrum of inhibition included Gram-positive and Gram-negative species. Thermophilic Lactobacillus, $L$ monocytogenes, some $P$ fluorescens strains and Enterobacteriaceae were markedly inhibited. In particular, $\mathrm{Lb}$ delbrueckii subsp bulgaricus B397 and Lb helveticus PR4 showed a zone of inhibition larger than $5.0 \mathrm{~mm}$. $P$ fluorescens ATCC 948 was not sensitive to the antimicrobial compound produced by itself.

Similar results were obtained by using the culture supernatant of $P$ fluorescens M22 and M40 strains, but only a narrow spectrum of inhibition (including a few Pseudomonas strains and Proteus vulgaris) was determined with the other 18 pseudomonad strains tested (data not shown).

\section{Purification of the antimicrobial compound}

The antimicrobial compound produced by $P$ fluorescens ATCC 948 in BN broth was purified by precipitation with ammonium sulphate and subsequent chromatography steps (table II). On the S-Sepharose column, the most inhibitory fractions were eluted near the start of the salt gradient (fig 1a) and were separated from most of the protein contained in the ammonium sulphate precipitated. Chromatography on Superose 12 (fig 1 b) resolved the fractions with inhibitory activity into one major peak corresponding to the lowest protein peak. The final purification was achieved on a Mono-Q anion exchange column (fig 1c); the peak of activity was superimposed on the second protein peak. The antimicrobial compound produced from $P$ fluorescens ATCC 948 was purified 260 -fold with a final yield of $6 \%$ and specific activity of $9750 \mathrm{AU} / \mathrm{mg}$ (table II).
SDS-PAGE showed that the enzyme preparation was homogeneous, with an apparent molecular mass of $67 \mathrm{kDa}$ (fig 2).

\section{Characterization of the antimicrobial compound}

The purified antimicrobial compound produced by $P$ fluorescens ATCC 948 was assayed for heat sensitivity and activity of hydrolytic enzymes. It was resistant to treatment at $80^{\circ} \mathrm{C}$ for $15 \mathrm{~min}$, but the inhibitory activity was completely abolished by treatment at $100{ }^{\circ} \mathrm{C}$ for $5 \mathrm{~min}$. The antimicrobial compound was insensitive to $\alpha$-amylase and lipase enzymes and was inactivated by all the proteolytic enzymes used. A representative plate with inactivation by trypsin, proteinase $\mathrm{K}$ and heat treatment at $100{ }^{\circ} \mathrm{C}$ for $5 \mathrm{~min}$ is shown in figure 3 .

The addition of the concentrated culture supernatant of $P$ fluorescens ATCC 948 to a culture of $L b$ fermentum D1 3 in MRS broth rapidly inactivated the sensitive cells (fig 4). After $6 \mathrm{~h}$ of incubation, the number of viable cells decreased from $\log 5.2$ to $\log$ $2.6 \mathrm{cfu} / \mathrm{mL}$ and to $\log 1.2 \mathrm{cfu} / \mathrm{mL}$ after $9 \mathrm{~h}$. No growth was observed after exposure ( 9 h) of Lb fermentum D13 to the lowest inhibitory concentration of the compound and subsequent cultivation ( $48 \mathrm{~h}$ ) in MRS containing the 1:5 diluted antimicrobial substance. This result indicated that the compound produced by $P$ fluorescens ATCC 948 seems to have a bactericidal action.

The production of the antimicrobial compound did not begin before the early exponential phase of growth $(\sim \log 4.8 \mathrm{cfu} / \mathrm{mL})$ and rapidly increased during the last stages of growth (fig 5). The highest production of the antimicrobial compound was detected after $72 \mathrm{~h}$ of incubation at $28^{\circ} \mathrm{C}$ followed by a decrease, probably due to the partial hydrolysis of the proteinaceous compound by extracellular proteinases (data not 
Table II. Purification of the proteinaceous compound from the culture supernatant of P fluorescens ATCC 948.

Purification du composé protéinique présent dans le surnageant de la culture de $\mathrm{P}$ fluorescens ATCC 948.

\begin{tabular}{lccccc}
\hline Purification step & $\begin{array}{c}\text { Total protein } \\
(\mathrm{mg})\end{array}$ & $\begin{array}{c}\text { Total activity } \\
(\mathrm{AU})\end{array}$ & $\begin{array}{c}\text { Specific activity } \\
(\text { AU/mg) }\end{array}$ & $\begin{array}{c}\text { Yield } \\
(\%)\end{array}$ & $\begin{array}{c}\text { Purification } \\
(- \text { fold })\end{array}$ \\
\hline Culture supernatant & 1652 & $6.2 \times 10^{4}$ & 37.5 & 100 & 1 \\
$\left(\mathrm{NH}_{4}\right)_{2} \mathrm{SO}_{4}$ & 617 & $4.7 \times 10^{4}$ & 76.2 & 76 & 2 \\
$\quad$ precipitation & 52 & $1.9 \times 10^{4}$ & 365.4 & 30 & 10 \\
S-Sepharose & 4 & $8.8 \times 10^{3}$ & 2200 & 14 & 58 \\
Superose 12 & 0.4 & $3.9 \times 10^{3}$ & 9750 & 6 & 260 \\
Mono-Q & & & & & \\
\hline
\end{tabular}

Total activity is expressed as arbitrary units (AU) of inhibitory activity (Barefoot and Klaenhammer, 1983). Specific activity was defined as AU per mg protein.

Fig 1. Purification of the proteinaceous antimicrobial compound from P fluorescens ATCC 948: protein concentration $(\square)$, inhibitory activity $(\boldsymbol{\Delta})$ and $\mathrm{NaCl}$ gradient $(---)$. a. Cation-exchange chromatography on S-Sepharose. b. Gel filtration on Superose 12. c. Anionexchange chromatography on Mono-Q.

Purification du composé protéinique à activité antimicrobienne produit par $\mathrm{P}$ fluorescens ATCC 948, concentration protéique $(\square)$, activité inhibitrice ( $\mathbf{\Delta})$ et gradient de $\mathrm{NaCl}(---)$. a. Chromatographie à échange cationique sur S-Sepharose. b. Gel filtration sur Sephacryl 200.c. Chromatographie à échange anionique sur Mono- $Q$.

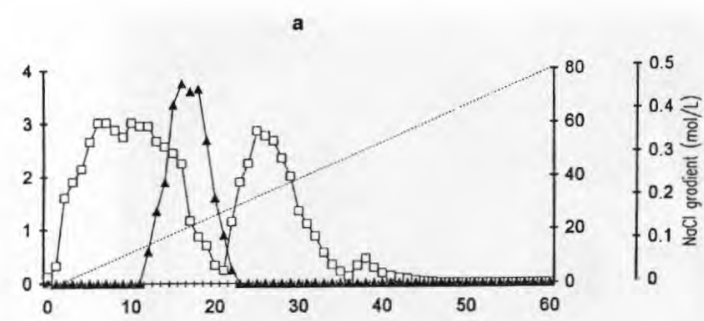

b

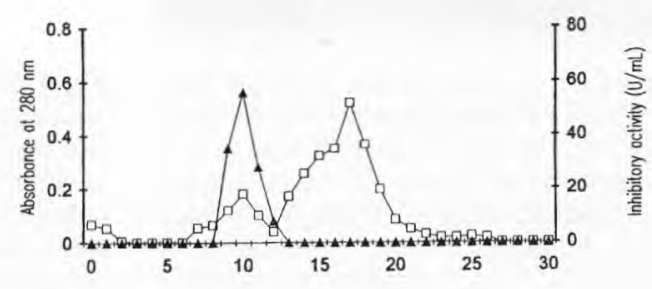

c

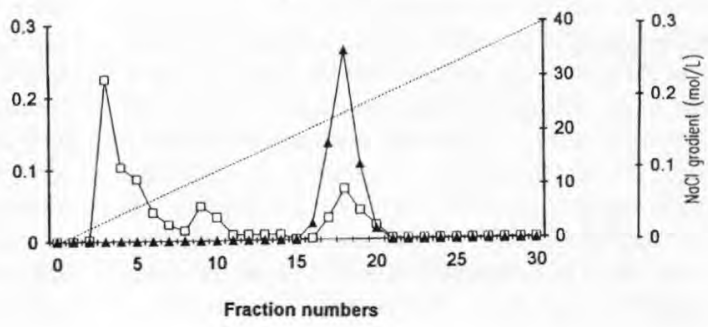



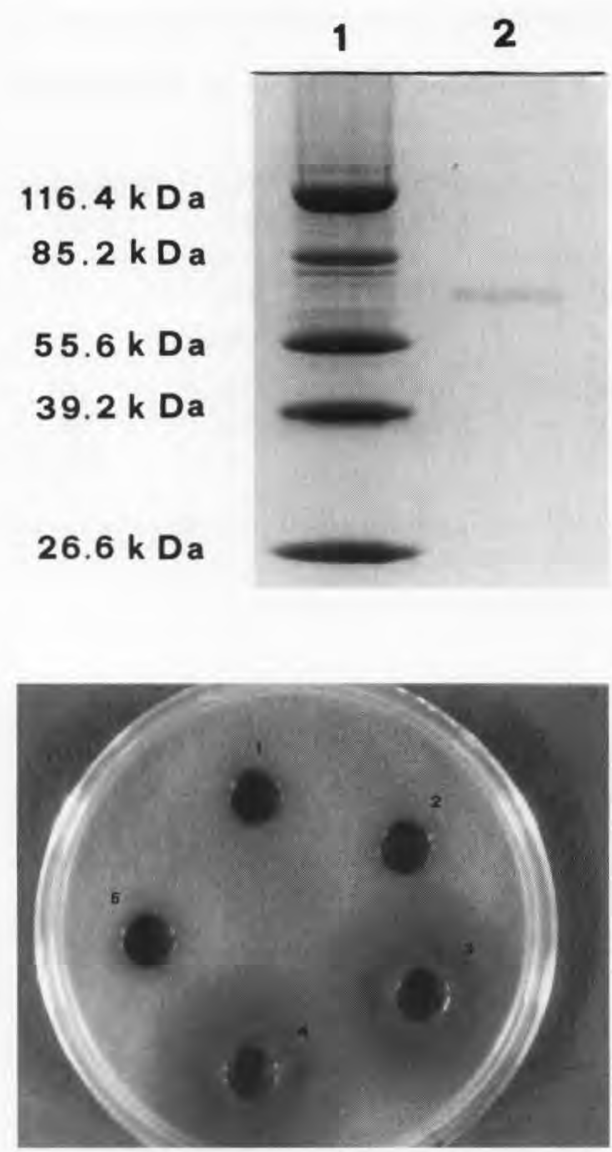

Fig 3. Inhibition of $\mathrm{Lb}$ fermentum D13 by $P$ fluorescens ATCC 948 proteinaceous antimicrobial compound by the agar well-diffusion assay. Wells contained the filtered $(0.22 \mu \mathrm{m})$ antimicrobial compound solution, which was treated by trypsin $(0.5 \mathrm{mg} / \mathrm{mL}$ ) (well 1$)$, proteinase $\mathrm{K}$ $(0.5 \mathrm{mg} / \mathrm{mL})$ (well 2$), \alpha$-amylase $(0.5 \mathrm{mg} / \mathrm{mL})$ (well 3 ), lipase $(0.5 \mathrm{mg} / \mathrm{mL}$ ) (well 4 ) and by treatment for $5 \mathrm{~min}$ at $100^{\circ} \mathrm{C}$ (well 5).

Inhibition de Lb fermentum D13 par le composé protéinique à activité antimicrobienne produit par P fluorescens ATCC 948 mise en évidence par la technique de diffusion en puits. Les puits contenaient la solution du composé antimicrobien filtré $(0,22 \mu \mathrm{m})$, traitée à la trypsine $(0,5 \mathrm{mg} / \mathrm{mL})$ (puits 1$)$, à la protéinase $K$ $(0,5 \mathrm{mg} / \mathrm{mL})$ (puits 2), à l' $\alpha$-amylase $(0,5 \mathrm{mg} / \mathrm{mL})$ (puits 3), à la lipase $(0,5 \mathrm{mg} / \mathrm{mL})$ (puits 4) et par traitement pendant 5 min à $100^{\circ} \mathrm{C}$ (puits 5).
Fig 2. The SDS-PAGE of the purified proteinaceous antimicrobial compound from $P$ fluorescens ATCC 948. Lane 1, reference proteins; lane 2, purified proteinaceous antimicrobial compound.

SDS-PAGE du composé protéinique à activité antimicrobienne produit par $\mathrm{P}$ fluorescens $A T C C$ 948. Ligne 1, protéines de référence; ligne 2, composé protéinique purifié à activité antimicrobienne.

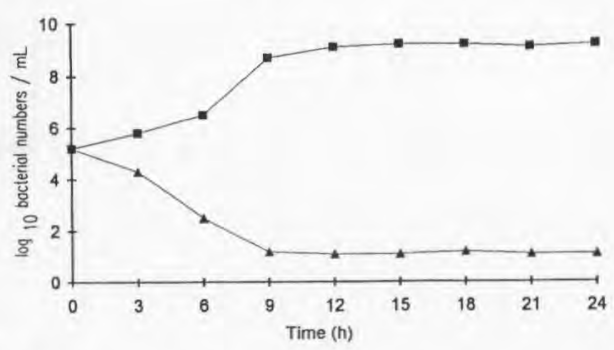

Fig 4. Bactericidal effect of the proteinaceous antimicrobial compound produced by $P$ fluorescens ATCC 948 on a sensitive strain ( $\mathrm{Lb}$ fermentum D13). ( $\mathbf{\Delta})$, addition of a concentrated culture supernatant from $P$ fluorescens ATCC 948 in MRS containing $\log 5.2 \mathrm{cfu} / \mathrm{mL}$ of $\mathrm{Lb} \mathrm{fer}$ mentum D13; ( $)$, addition of a concentrated culture supernatant from $P$ fluorescens M8 not a producer of proteinaceous antimicrobial compound.

Effet bactéricide du composé protéinique à activité antimicrobienne produit par $\mathrm{P}$ fluorescens ATCC 948 contre une souche sensible (Lb fermentum D13); ( $\boldsymbol{\Delta})$, adjonction d'un surnageant de culture concentré de $\mathrm{P}$ fluorescens ATCC 948 dans MRS contenant log 5,2 cfu/mL de Lb fermentum D13; ( $\boldsymbol{\square})$, adjonction d'un surnageant de culture concentré produit par $\mathrm{P}$ fluorescens M8 non producteur de composé protéinique à activité antimicrobienne. 


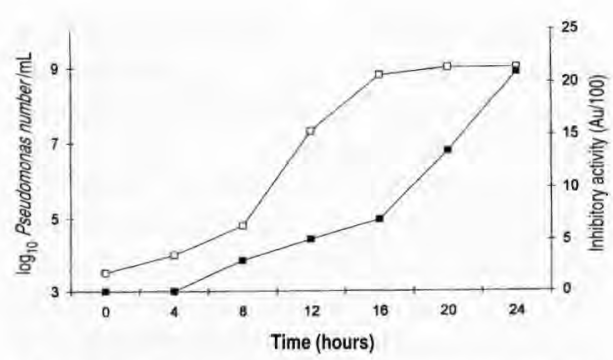

Fig 5. Production of the proteinaceous antimicrobial compound from $P$ fluorescens ATCC 948 (घ) during the growth period ( $\square$ ).

Production du composé protéinique à activité antimicrobienne par P fluorescens ATCC 948 (ש) pendant la période de développement $(\square)$.

by extracellular proteinases (data not shown).

The optimum $\mathrm{pH}$ for producing the antimicrobial compound was 6.5 (fig 6a). The compound produced showed stability from $\mathrm{pH} 3.0$ to 8.0 (data not shown).

Optimal production of the proteinaceous compound was at $20^{\circ} \mathrm{C}$ (fig 6b), which did not coincide with the optimal growth of $P$ fluorescens ATCC 948 (data not shown). A relatively high production was also observed at low temperatures $\left(5\right.$ to $\left.15^{\circ} \mathrm{C}\right)$. The antimicrobial compound was stable after 45 days at $\sim 15^{\circ} \mathrm{C}$, but a decrease in activity was observed on the freeze-dried compound after 15 days of storage at $-20^{\circ} \mathrm{C}$.

Similar results concerning the characterization of the antimicrobial compound were obtained by cultivating $P$ fluorescens ATCC 948 in BN medium or in skim milk.

\section{DISCUSSION AND CONCLUSION}

A $67-\mathrm{kDa}$ proteinaceous compound with inhibitory activity against unrelated Gramnegative and Gram-positive species has been

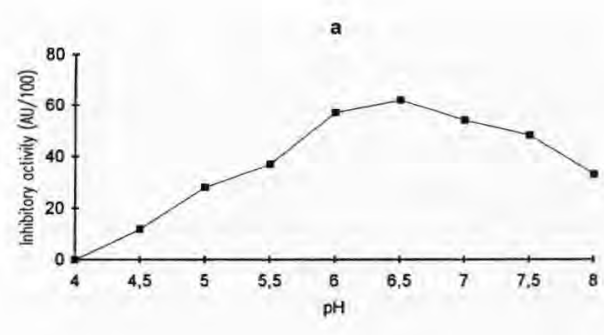

b

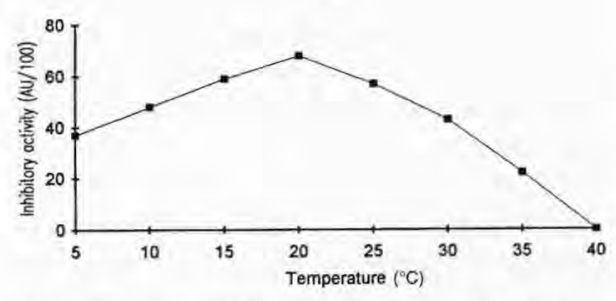

Fig 6. Effect of $\mathrm{pH}$ (a) and temperature (b) on the production of the proteinaceous antimicrobial compound from $P$ fluorescens ATCC 948.

Effet du pH (a) et de la température (b) sur la production du composé protéinique à activité antimicrobienne produit par $\mathrm{P}$ fluorescens ATCC 948.

extracellularly produced and purified from $P$ fluorescens ATCC 948. The inhibition was shown to be particularly marked on thermophilic Lactobacillus, and the strain of $L$ monocytogenes tested was also inhibited.

Psychrotrophic pseudomonads have been extensively studied for their production of antimicrobial compounds, which play an important role in the biocontrol of plant diseases (Dowling and O' Gara, 1994). Most of them (indoles, phenazines, lipids, antibiotics and pterines) are not of protein nature or represent complex substances in which the protein is not the only biologically active moiety. Siderophores, produced by pseudomonads, are high-affinity iron transport molecules which could sequester available 
iron and reduce the activity of the electron transfer proteins, of the enzyme involved in hydrogen peroxide and oxygen metabolism, as well as the activity of the DNA biosynthetic enzymes (Freedman et al, 1989). Well-diffusion assays conducted in the presence of iron-supplemented media showed inhibitory activity similar to that determined without integration (data not shown), excluding the role of siderophores in the antimicrobial activity of $P$ fluorescens ATCC 948. An antagonism linked to bacterial viruses contained in the extracellular culture filtrate has been shown in pseudomonads (Vidaver, 1983; Smidt and Vidaver, 1986) and other microbial species (De Klerk and Coetzee 1961; Betz and Anderson, 1964; Hamada and Ooshima, 1975). Dilutions of the antimicrobial preparation from $P$ fluorescens ATCC 948 produced smaller zones of inhibition and did not increase plaque formation (data not shown), thus also excluding the presence of viruses in the culture supernatant. Antibiotics and complex toxins (syringomycin and syringotoxin) are also produced by Pseudomonas strains (Iacobellis et al, 1992; Dowling and O'Gara 1994). The proteinaceous nature of the antimicrobial compound purified in this study, together with the high molecular mass and the absence of carbohydrate and lipid moities (treatments with acetone and nbutanol did not modify the inhibitory activity of $P$ fluorescens ATCC 948 supernatant) (Iacobellis et al, 1992) seem to exclude the compound from this category. Bacteriocins with features quite similar to those determined for the antimicrobial compound produced by $P$ fluorescens ATCC 948 (active protein moiety, molecular mass of $\sim 60 \mathrm{kDa}$, optimal production at $20^{\circ} \mathrm{C}$ and a certain degree of thermostability) have been shown in $P$ syringae $\mathrm{pv}$ syringae (Smidt and Vidaver, 1986), $P$ syringae susbp savastanoi (Iacobellis et al, 1995), $P$ solanacearum (Cuppels et al, 1978), $P$ phaseolicola and $P$ glycinea (Vidaver et al, 1972). By comparing these studies, the main difference lies in a narrower spectrum of activity, in some cases species-specific, which characterizes the isolated bacteriocins. A bacteriocin-like compound recently characterized for $P$ fluorescens from fish (Champomier-Vergès and Richard, 1994), has shown inhibition against related pseudomonad pathogens. Nevertheless, inhibition against some unrelated Gram-negative (Escherichia coli and Erwinia), and Grampositive (Bacillus cereus and Listeria spp) species and fungi has been shown by a few strains of $P$ syringae, $P$ phaseolicola, $P$ glycinea (Vidaver et al, 1972), P cepacia (Abe and Nakazawa, 1994), $P$ aeruginosa (Rasool and Khan, 1993) and by fluocins from $P$ fluorescens (Hamon et al, 1961), not excluding the synthesis of broad range bacteriocins. Only three strains (ATCC 948, M22 and M40) among the 21 P fluorescens strains tested in this study have shown a similar wide spectrum of activity.

Based on extensive studies of the colicins produced by Gram-negative bacteria, Tagg et al (1976), and subsequently Jack et al (1995) suggested six criteria for characterizing bacteriocins mainly produced by Gram-positive microorganisms, and proposed the definition 'bacteriocin-like inhibitory substance' for proteins which are not widely accepted or genetically characterized. Exceptions to these six criteria have been noted. Montville and Kaiser (1993) hold that there are only two requisites for bacteriocins: their proteinaceous nature and their lack of lethality to cells which produce them. The antimicrobial compound produced by $P$ fluorescens ATCC 948 is of protein nature, not lethal for the producing strain, with a bactericidal mode of action but which shows a broad spectrum of activity. As a consequence of these features we decided, before further characterization (mass spectrometry and genetic studies), not to include it in the bacteriocins but to simply define it as a "proteinaceous compound with a broad range of inhibitory activity'. 
Psychrotrophic pseudomonads have been extensively studied for their proteolytic enzymes which cause spoilage in dairy products (de Koning et al, 1985; Gobbetti, 1993). A correlation between cell growth during the cold storage of raw milk and the production of extracellular proteinases has been shown (Mottar, 1989). This study shows that $P$ fluorescens ATCC 948 when grown in skim milk produces an antimicrobial compound with inhibitory activity against thermophilic Lactobacillus (especially one strain of Lb delbrueckii subsp bulgaricus B397 and of Lb helveticus PR4 were inhibited). Mesophilic Lactobacillus and other lactic acid bacteria strains have a limited sensitivity or are insensitive. The proteinaceous compound, optimally produced at $\mathrm{pH} 6.5$, shows the highest rate of production within $72 \mathrm{~h}$ of incubation (the synthesis began during the early exponential phase of growth, $\log 4.8 \mathrm{cfu} / \mathrm{mL}$ ), is resistant to pasteurization, is stable at $15^{\circ} \mathrm{C}$ for 45 days and maintains more than $50 \%$ of the maximum inhibitory activity in the temperature range of 5 to $10^{\circ} \mathrm{C}$, which coincides with a limited growth of the psychrotrophic strain. Even though the microbial relationships have to be considered in a complex interactive dynamic, these features raise another problem linked to the excessive growth of psychrotrophic pseudomonads in raw milk.

Considering its importance in the dairy field and, in food microbiology, in general (inhibition of foodborne bacteria), mass spectrometry and genetic studies of this antimicrobial compound from $P$ fluorescens ATCC 948 are warranted.

\section{REFERENCES}

Abe M, Nakazawa T (1994) Characterization of hemolytic and antifungal substance, cepalycin, from Pseudomonas cepacia. Microbiol Immunol 38, 1-9

Balasubramanyam BV, Varadaraj MC (1994) Dahi as a potential source of lactic acid bacteria active against foodborne pathogenic and spoilage bacteria. I Food Sci Technol (Mysore) 31, 241-243
Barefoot SF, Klaenhammer TR (1983) Detection and activity of lactacin B, a bacteriocin produced by Lactobacillus acidophilus. Appl Environ Microbiol 45, 1808-1815

Betz JV, Anderson KE (1964) Isolation and characterization of bacteriophages active on Clostridium sporogenes. I Bacteriol 87, 408-415

Bradford M (1976) A rapid and sensitive method for the quantitation of microgram quantities of protein utilizing the principle of protein-dye binding. Anal Biochem 72, 248-254

Champagne CP. Girard F, Morin N (1990) Inhibition of the psychrotrophic bacteria of raw milk by addition of lactic acid bacteria. J Food Prot 53 , 400-403

Champomier-Vergès MC, Richard J (1994) Antibacterial activity among Pseudomonas strains of meat origin. Letl Appl Mícrobiol 18, 18-20

Cousin MA (1982) Presence and activity of psychrotrophic microorganisms in milk and dairy products: a review. J Food Prot 45,172-180

Cuppels DA, Hanson RS, Kelman A (1978) Isolation and characterization of a bacteriocin produced by Pseudomonas solanaceanum. J Gen Microbiol 109 , 295-303

De Klerk HC, Coetzee JN (1961) Antibiosis among lactobacilli. Nature (Lond) 192. 340-341

De Koning PJ, Kaper J, Rollema HS, Driessen FM (1985) Age-thinning and gelation in unconcentrated and concentrated UHT-sterilized skim milk. Effect of native milk proteinase. Neth Milk Dairy J 39. $71-87$

De Man JC, Rogosa M, Sharpe ME (1960) A medium for the cultivation of lactobacilli. J Appl Bacteriol $23,1538-1541$

Dowling DN, O' Gara F (1994) Metabolites of Pseudomonas involved in the biocontrol of plant disease. Trends Biotechnol 12, 133-141

Freedman DJ, Kondo JK, Willrett DL (1989) Antagonism of foodborne bacteria by Pseudomonas spp: a possible role for iron. I Food Prot 52, 484-489

Gobbetti M (1993) La protéolyse des laits et les défauts qu'elle peut entraîner. Rev Enil 174, 42-50

Gobbetti M, Rossi J (1992) Peptidases of Pseudomonas fluorescens: identification and properties. J Dairy Sci 75, 924-934

Griffiths MW, Phillips JD, Muir DD (1981) Thermostability of proteases and lipases from a number of species of psychrotrophic bacteria of dairy origin. I Appl Bacteriol 50, 289-295

Hamada S, Ooshima T (1975) Inhibitory spectrum of a bacteriocin-like substance (mutacin) produced by some strains of Streptococcus mutans. J Dent Res 54, 140-145

Hamon Y, Véron N, Péron Y (1961) Contribution à l'étude des propriétés lysogènes et bactériocinogènes dans le genre Pseudomonas. Ann Inst Pasteur 101, 738-753 
Iacobellis NS, Lavermicocca P, Surico G, Durbin RD (1992) The occurrence and characterization of a syringomycin-macromolecular complex in cultures of Pseudomonas syringae pv syringae. Physiol Mol Plant Pathol 40, 91-105

Iacobellis NS, Contesini AM, Surico G (1995) Bacteriocin production by Pseudomonas syringae subsp savastanoi. Phytopathol Mediterr 34, 15-22

Jack RW, Tagg JR, Ray B (1995) Bacteriocins of Gram-positive bacteria. Microbiol Rev 59, 171-200

Jaspe A, Fernandez L, Palacios P, Sanjose C (1995) Interaction between Pseudomonas fluorescens and lactic starter Hansen No 44 in milk at $7^{\circ} \mathrm{C}$, Milchwissenschaft 50, 607-610

Koburger JA, Claydon TJ (1961) Identification of substances in milk cultures of Pseudomonas fluorescens which stimulate lactic starter cultures. J Dairy Sci 44, 1811-1817

Laemmli UK (1970). Cleavage of structural proteins during the assembly of the head of bacteriophage T4. Nature (Lond) 227, 680-685

Mans De Marion MC, Raffellini SM, Fantuzzi L, Gonzalez FC (1995) Inhibitory effect of Leuconostoc mesenteroides subsp dextranicum on Pseudomonas fluorescens in milk stored at low temperature. Aust J Dairy Technol 50, 1-5

Mitsuhashi S, Murata N (1991) Inhibitory activity of Bifidobacterium on the growth of Gram-negative and Gram-positive bacteria. J Jpn Soc Nutr Food Sci 44, 365-372

Montville TJ, Kaiser AL (1993) Antimicrobial proteins: classification, nomenclature, diversity, and relationship to bacteriocins. In: Bacteriocins of Lactic Acid Bacteria (Hoover DH, Steenson LR, eds) Academic Press Inc, New York
Mottar JF (1989) Effect on the quality of dairy products. In: Enzymes of Psychrotrophs in Raw Food (McKellar RC, ed) CRC Press, Boca Raton, FL

Rasool SA, Khan MKZ (1993) Broad-range bacteriocins of indigenous pseudomonads: in vivo manipulation and molecular characterization. Pakistan J Sci Ind Res 36, 373-376

Reeves P (1965) The bacteriocins. Bacteriol Rev 29, 24-45

Schillinger U, Lücke FK (1989) Antibacterial activity of Lactobacillus sake isolated from meat. Appl Environ Microbiol 55, 1901-1906.

Smidt ML, Vidaver AK (1986) Isolation and characterization of syringacin W-1, a bacteriocin produced by Pseudomonas syringae pv syringae. Can J Microbiol 32, 231-236

Tagg JR, Dajani AS, Wannamaker LW (1976) Bacteriocins of Gram-positive bacteria. Bacteriol Rev $40,722-756$

Tayfour A, Milliere JB, Veillet-Poncet L (1981) Etude comparative du comportement de Streptococcus lactis, Streptococcus thermophilus et Lactobacillus bulgaricus dans des laits et des rétentats pasteurisés après stockage à l'état cru à basse température. Lait 61, 149-170

Varadaraj MC, Nirmala-Devi S, Keshava N, Manjrekar SP (1993) Antimicrobial activity of neutralized extracellular culture filtrates of lactic acid bacteria isolated from a cultured Indian milk product ('dahi'), Int J Food Microbiol 20, 259-267

Vidaver AK (1983) Bacteriocins: the lure and the reality. Plant Dis 5, 471-475

Vidaver AK, Mathys ML, Thomas ME, Schuster ML (1972) Bacteriocins of the phytopathogens Pseudomonas syringae, $P$ glycinea, and $P$ phaseolicola. Can J Microbiol 18, 705-713 